Article

\title{
Not Different Enough: Avoiding Representation as "Balkan" and the Constrained Appeal of Macedonian Ethno Music
}

\author{
Dave Wilson $(\mathbb{D}$ \\ New Zealand School of Music-Te Kōkī, Te Herenga Waka-Victoria University of Wellington, \\ Wellington 6011, New Zealand; dave.wilson@vuw.ac.nz
}

Received: 31 January 2020; Accepted: 25 March 2020; Published: 30 March 2020

\begin{abstract}
Since the early 1990s, interest in various forms of traditional music among middle-class urban ethnic Macedonians has grown. Known by some as the "Ethno Renaissance", this trend initially grew in the context of educational ensembles in Skopje and gained momentum due to the soundtrack of the internationally acclaimed Macedonian film Before the Rain (1994) and the formation of the group DD Synthesis by musician and pedagogue Dragan Dautovski. This article traces the development of this multifaceted musical practice, which became known as "ethno music" (etno muzika) and now typically features combinations of various traditional music styles with one another and with other musical styles. Ethno music articulates dynamic changes in Macedonian politics and wider global trends in the "world music" market, which valorizes musical hybridity as "authentic" and continues to prioritize performers perceived as exotic and different. This article discusses the rhetoric, representation, and musical styles of ethno music in the 1990s and in a second wave of "ethno bands" (etno bendovi) that began around 2005. Drawing on ethnography conducted between 2011 and 2018 and on experience as a musician performing and recording in Macedonia periodically since 2003, I argue that, while these bands and their multi-layered musical projects resonate with middle-class, cosmopolitan audiences in Macedonia and its diaspora, their avoidance of the term "Balkan" and associated stereotypes constrains their popularity to Macedonian audiences and prevents them from participating widely in world music festival networks and related markets.
\end{abstract}

Keywords: world music; Balkan; ethno music; Macedonia; North Macedonia; representation; čalgija; Aegean Macedonia

\section{Introduction}

Combinations of traditional music and contemporary musical styles have captured the attention of musicians, audiences, scholars, and music industry professionals for decades, with responses ranging from thrill and inspiration to concern, vexation, and anger. Musical production in this vein has followed colonial and other pathways of globalization, as recordings and live performances have circulated sounds along networks of cultural flow. Scholars have productively interrogated these kinds of "hybrids" for differences in power, situating them in complex processes of political signification and as open to multiple interpretations (Meintjes 1990), exposing practices that exploit indigenous music makers for profit (Feld 1996, 2000a, 2000b; Guy 2002; Taylor 2003) and exploring the ways "world music" industry personnel grapple with issues of representation as they promote artists on the festival circuit and along related networks (Whitmore 2016). Particular attention has been paid to how middle-class American and European audiences seek an "authentic" experience of a band, with, somewhat ironically, hybridity being recently viewed as the strongest marker of authenticity (Taylor 1997; van Klyton 2014; Weiss 2014). Hybridity itself can take any number of forms, and different types 
of hybridity and their representations are valued by audiences variously, contingent on any number of factors. These audience preferences expand or constrain the appeal of a musician or group, directing the flow of reception along certain networks and not others.

In this article, I examine the case of a particular scene of this kind of hybrid music in North Macedonia known as "ethno music" (etno muzika). The musicians of this scene in their representational practices tend to avoid one of the most salient signifiers of music from southeast Europe in world music networks of hybridized music: the term "Balkan". The ethno music scene is characterized by music that combines traditional music styles from North Macedonia with one another and often also with jazz, European classical music, or any number of popular music styles. The term "ethno music" is often met with ambivalence by musicians of the scene and the public alike, and they also rarely represent ethno music as "Balkan" in marketing or discourse. Though musicians of the ethno music scene sometimes include elements of exoticization that typically play into the Balkan signifier, their avoidance of the term itself in their representation contributes to their constrained appeal among those outside North Macedonia and the Macedonian diaspora. In particular, the absence of the word Balkan as a signifier of difference contributes to their limited appeal to world music industry professionals and the broader festival scene and other networks to which they provide access.

The music of southeast Europe has been present on the world music scene since the 1970s, with the Bulgarian women's singing project Le Mystère des Voix Bulgares among the first to circulate internationally to American and west European audiences (Buchanan 2006), in step with a broader fascination with Balkan music among the baby boom generation (Laušević 2007). The term Balkan as a signifier of particular aesthetics in world music of the region became widespread in the 1990s and 2000s, linked at least in part to the rise of Goran Bregović (b. 1950) to global renown. Born in Sarajevo to a Croat father and Serb mother, Bregović is a self-styled composer of "Balkan music" who is celebrated internationally for his energetic performances of a pop-inflected Balkan "folk" music, notably including brass bands. He has also been subject to significant critique and anger for exploiting music of Romani musicians, appropriating it for his own personal material gain (Silverman 2012, pp. 275-80; Marković 2008 , 2009, 2013). In his representations of Romani music combined with other popular and traditional styles from throughout the region and beyond, Bregović relies on and re-inscribes the term Balkan as related to stereotypes of Gypsies (and Gypsy music) as wild and unbridled. This continues the legacy of ascribing the Balkans with fantastical ambiguity, representing them as Europe's "incomplete self", its internal Other (Todorova 2009, pp. 17-18). The Balkans, especially as related to hybridized musical styles marketed under the term, are "sufficiently primitive and exotic to be titillating but also near enough in geographic and cultural terms to feel safe to Western European audiences" (Marković 2015, p. 268). Musicians such as Bregović trade on the Balkan label in performances geared towards the "West" in a global market, rather than to audiences within the region (Hofman 2014, p. 43). This stands in contrast to Macedonian ethno bands, whose performances are primarily geared towards the Macedonian market.

As Balkan music gained fans on the world music scene outside southeast Europe, "Balkan Brass" became a catch-all term for Romani brass bands, though the label Balkanizes the ensembles and erases (or at least obscures) their Romani identity. Several Romani brass bands rose to international fame in the 1990s and 2000s including Fanfare Ciocărlia from Romania, Kočani Orkestar from North Macedonia, and groups led by Boban Marković and his son Marko. As is common for Romani musicians, all of these groups value combinations of styles and genres as they position themselves towards global networks and markets, negotiating economic and artistic forces (Silverman 2012, p. 291). In Serbia, Goran Bregović and Boban and Marko Marković have capitalized on and shaped the notion of "Balkan" music in this global scene, as has the related Guča Trumpet Festival, which has become a rich platform for musical exchange and a site for projecting and living out exoticist fantasies of the Balkans (Marković 2015, pp. 268-72). Brass bands in other parts of the world have followed these trends, including Slavic Soul Party! (New York), Inspector Gadje (San Francisco), and Panorama Brass Band (New Orleans), all of which practice some form of hybridization of Romani brass band music with other 
musical styles, genres, or repertoires. ${ }^{1}$ The term Balkan has also appeared in the names of musical groups in Serbia outside the brass scene that hybridize traditional musics with contemporary styles and genres (e.g., Balkanopolis, Balkanika, Balkan Salsa Band). These bands similarly position their music towards the "West" along similar tropes of representation of the Balkans and are part of the Serbian "ethno music" scene, which is a separate phenomenon from ethno music in North Macedonia that has manifested in particularly different ways (Medić 2014). Serbian audiences of ethno music, similar to those of other musics that use the term Balkan, participate in the incorporation of Balkan clichés into their self-perceived national identity, a process Marija Dumnić (2012, pp. 348-49) has called "autobalkanism".

By contrast, while Macedonian ethno bands and musicians tend to embrace typical discourses connected to the region concerning blurred borders and destabilizing dichotomous constructs of east and west, they turn away from exoticizing tropes of the Balkans that could appeal to the gaze of world music professionals and their audiences and networks (Whitmore 2016). Though the meaning of the concept "Balkan" is not fixed in North Macedonia, it tends to be consistently associated with at least some sense of "backwardness". ${ }^{2}$ In contrast, North Macedonia itself has often been conceived by Macedonians as a land of promise engulfed by its "Balkan" neighbors, what Vasiliki Neofotistos, drawing on Milica Bakić-Hayden's (1995) "nesting orientalisms", calls "the Balkan's Other within" (Neofotistos 2008). I argue that in these musicians' avoidance of the term Balkan and its musical and representational associations, they refuse to be situated as either an internal Other or an incomplete European self, situating themselves rather as complete cosmopolitan global (European) subjects participating in sophisticated multicultural projects. ${ }^{3}$ They focus on the Macedonian roots of their music, as well as the ways that their music layers multiple musical traditions from within Macedonian borders on top of one another (including Romani ones) along with contemporary jazz, blues, rock, and other popular styles. In this way, Macedonian ethno music becomes a cosmopolitan celebration of the Macedonian nation as belonging to a diverse and cosmopolitan Europe, with ethnic Macedonians, and Macedonian musical traditions, at the center (and benefitting the most). In a version of Thomas Turino's (2000) twin paradoxes of nationalism, middle-class musicians and audiences at the core of Macedonian ethno music both reaffirm their ethnonational identity as Macedonians and inscribe themselves, the spaces they inhabit, and Macedonian traditional music itself as cosmopolitan (Tochka 2017; see also Wilson 2019). Similar to other musical cosmopolitans in southeast Europe, these musicians end up producing "music designed for the most part for local consumption (i.e., within the nation-state), and with local, rather than pan-regional, needs, desires, and contexts very much to the fore" (Stokes 2007, p. 310).

1 Another element of this wave of Balkan fever was the "Balkan Beat" scene, which also reached its peak in the 1990s and 2000s. In this scene, bands such as New York-based Balkan Beat Box and DJs such as Shantel remix recordings of brass band music and combine it with hip hop, dancehall, electronica, and other beats (Marković 2013; Silverman 2013).

2 Though the meaning of "Balkan" in Macedonia has perhaps changed over the years (and is, in any case, uneven and contingent), what is consistent for the case of ethno musicians is their general avoidance of the term. This suggests that, because Balkan is likely to be associated, at least in part, or by some sector of the population, with backwardness, musicians continue to avoid it and its negative associations, even if those associations would bring profit and fame. If Macedonia is understood as marginalized vis-à-vis Europe (as is often the case among Macedonians), it could be suggested that these musicians reject strategic essentialism (Spivak 1987) and instead employ a strategic nationalized cosmopolitanism of sorts.

3 Macedonian participation in a European cosmopolitanism has typically been linked in part to desires for full membership of Macedonia in the European Union. The political stability and economic prosperity promised by the prospect of EU membership are reflected in imaginings of the "West", which can be played out in the enactment of cosmopolitanisms perceived to be European, musical and otherwise (Neofotistos 2008). "Being European" in Macedonia is about consumption, about having freedom to travel abroad and, for women, about possessing and idealized slender female body (Dimova 2003; Thiessen 2006), as well as about demonstrating a heritage of Macedonia as a cornerstone of Western civilization (Neofotistos 2011). It is also, I suggest, about performing a musical cosmopolitanism that goes "beyond your little horizon" (Nii Noi Nortey in Feld 2012, p. 90) and that hybridizes musical practices in a way perceived as European, celebrating combinations of styles and hesitating to invite an exoticizing gaze. 
In the discussion that follows, I trace the development of ethno music in Macedonia ${ }^{4}$ first in the 1990s and then in a second wave of ethno bands that began around 2005. I focus on the most prominent musicians involved in the initial emergence of ethno music in the 1990s and focus on some of the more well-known musicians of ethno music's second wave, all of which serve as emblematic examples of ethno music's sounds and practices. Undergirding the development of ethno music are the ongoing challenges to the existence of a distinctive Macedonian nation and culture, primarily by Greece. These challenges have arguably stimulated greater focus on and articulation of musical representations of Macedonia among musicians involved in ethno music, in a national context where international recognition of Macedonian cultural production as distinctively Macedonian is highly valued. While ethno music first arose in 1990s as a national response to the international recognition of the Macedonian film Before the Rain (1994) and of its score (and, by proxy, of a distinctive Macedonian nation and culture), artists in the second wave of ethno music such as Ljubojna and Chalgia Sound System, as well as ethno-music-inspired pop singer Karolina Gočeva, seek international recognition for their own musical representations of Macedonia. As they draw on musical sounds that affirm and expand on the musical constructs of the Macedonian nation, such as songs of the Aegean Macedonia region and elements of the urban Ottoman genre čalgija, musicians and artists of second-wave ethno music often achieve renown within Macedonia and the diaspora. However, in their efforts to reaffirm the richness of music in Macedonia as belonging to a cosmopolitan Europe and in their avoidances of exoticizing tropes of the Balkans, their appeal to audiences beyond Macedonian ones is constrained.

\section{Ethno Music in the 1990s: Before the Rain and DD Synthesis}

Macedonians use the terms "ethno bands" (etno bendovi) and "ethno music" (etno muzika) to generally and informally refer to music involving elements (e.g., instrumentations, styles, and/or repertoires) of traditional music (tradicionalna muzika) in some new configuration or in combination with some contemporary style. Tradicionalna muzika is often used as a catch-all phrase for several genres of music in Macedonia, especially among audiences of ethno bands, and sometimes among musicians. One of these genres, narodna muzika (rural village music), includes izvorna muzika (music from the "source" or "wellspring") or rural village music that was passed down by oral tradition, arrangements of izvorna muzika for staged ensembles, and novokomponirana narodna muzika (newly-composed folk music) or new music composed in styles of narodna muzika, a practice with roots in the Yugoslav period (Rasmussen 2002). Another is starogradska muzika (old urban music), which first arose in the late nineteenth and early twentieth centuries in connection to the rise of an urban bourgeoisie under the Ottoman Empire. It often combines instruments of the symphony orchestra, such as the violin and the clarinet, with narodni instruments, such as the kanun (plucked zither) and the $u t$ (short-necked fretless pear-shaped lute) (Seeman 2012). In their combinations of these styles with one another and with contemporary styles, middle-class ethnic Macedonian performers and audiences comprise the core of the ethno band scene, though ensembles frequently involve Romani musicians and occasionally ethnic Albanians, such as Muhamed Ibrahimi (guitar, mandolin, saz). ${ }^{5}$

The development of ethno music in Macedonia can be traced musically to two occurrences of international acclaim for Macedonian cultural production in the 1990s: (1) the 1994 release of Milčo

4 North Macedonia was established as the Republic of Macedonia in 1991 and officially changed its constitutional name to the Republic of North Macedonia in 2019. The Prespa Agreement, signed by Greek and Macedonian leaders in 2018 and officially settling a long-running dispute on the country's name, set the terms for the name change. The agreement establishes the word "Macedonian" as the official way to refer to the nationality of citizens of North Macedonia and "Macedonian language" as the name of the official language of North Macedonia (Albanian is also an official language in North Macedonia). When referring to the country before 2019, I often use "Macedonia" or "The Republic of Macedonia" for accuracy. I use "Macedonian" throughout, consistent with the Prespa Agreement and with common usage both before and after the agreement.

5 In 2014, Ibrahimi released an instrumental album, Fly (PMG Records), that could be considered an ethno music project. Ibrahimi had been part of the Macedonian/Albanian rock band Bla Bla Bla in the 1990s but had not been active since around 2000 . 
Mančevski's film Before the Rain and its subsequent Oscar nomination for Best Foreign Language Film and (2) the subsequent formation and ensuing popularity of the band DD Synthesis. The success of Before the Rain and DD Synthesis are best understood in the context of the obstacles Macedonia faced to receiving recognition in international forums under its constitutional name after it was established as the Republic of Macedonia in 1991 upon the breakup of Yugoslavia. Principal among these obstacles was opposition from Greece to admitting Macedonia to the United Nations or other international bodies, predicated on Greek ownership of the name "Macedonia" (Greece's northern province is also named Macedonia) and of numerous cultural symbols also claimed by Macedonia. Macedonia's membership in the United Nations was delayed, and Greece placed a trade embargo on Macedonia in early 1994 that lasted until the 1995 Interim Accord between the two nations. For Macedonians, lack of recognition of a distinct Macedonian culture and nation were seen as significant causes of ongoing political and economic challenges for the nation and its inhabitants. Musicians and filmmakers who could bring international attention to Macedonian music and film as Macedonian were celebrated in Macedonia and became trendsetters for what constituted success in the country as well. The ways that Before the Rain and, later, DD Synthesis engaged with various forms of traditional music thus set the stage for the development of ethno music.

Both Before the Rain and DD Synthesis built on musical trends from the "world beat" and "New Age" categories that had arisen in Europe and the United States in the 1980s. Le Mystère des Voix Bulgares and Balkana in Bulgaria had been spearheaded by American and European impresarios and gained traction among consumers in the New Age market. Similar to their predecessors, the score to Before the Rain and the music of DD Synthesis featured Macedonian traditional music in combination with timbres and textures that referenced New Age musical sensibilities. These timbres and textures, which include a fair amount of long, sustained drones and chords on synthesizers, had already come to index "meditational ambience and antediluvian, spiritualist overtones" (Buchanan 2006, p. 345; see also Taylor 1997), values at the core of the New Age genre. However, in contrast to the many cases where American and west European individuals have "discovered" and promoted various traditional musics as "world music" with sometimes dubious financial and ethical practices, ethno music in Macedonia was not primarily stimulated by foreign impresarios coming to Macedonia with an interest in promoting traditional music projects abroad. Rather, in place of the mediation of such impresarios, Before the Rain's global recognition as an Oscar nominee and the mechanisms of the film industry paved the way for the popularity of the music from the film and helped to inspire similar musical projects within Macedonia.

Dragan Dautovski (b. 1957) is one of the key figures in the development of the ethno music scene. Born in Berovo in east Macedonia, he received a degree in music theory and pedagogy from the Faculty of Musical Arts in the capital city, Skopje, not becoming interested in what he calls traditional music (tradicionalna muzika) until the last year of his studies. Initially working primarily as an elementary school teacher, he began leading a folklore ensemble (choir and folk-instrument orchestra) at a Skopje school in the late 1980s. He subsequently founded several ensembles. The first of those ensembles to receive significant exposure performed its debut concert at the 500-seat concert hall of the Army of the Republic of Macedonia in 1992. This amateur ensemble was called the "Mile Kolarovski" Orchestra of Narodni Instruments, which featured six vocalists and twelve instrumentalists—older narodni artists who had moved to Skopje from rural areas performing on kaval (end-blown flute), gajda (bagpipe), kemane (bowed spike fiddle), tapan (double-headed drum), and tambura (plucked/strummed fretted long-necked lute). In Dautovski's words to me in an interview:

At that time there was a very rigid — and there still is—division between village culture and city (gradska) culture. But that transition, the village/city, a synthesis, a blending was being made in that period, it was practically a revolution in culture. All of a sudden you could see tons of [...] kids carrying kavals [in the city]. That had only happened in the villages previously [...] In that period a philosophy was prevalent among the young people, that you 
need to return to the tradition, so that you can find your identity-your personal artistic identity - whether in visual arts or in terms of a musical identity.

While various styles of traditional music had been fostered in Yugoslav-era institutions as markers of Macedonian national identity, this growing interest in traditional music recognized by Dautovski demonstrates how, for youth of the city, performing these styles of music began to serve as an affirmation of a unique and distinct national Macedonian identity in the face of challenges to that identity.

Dautovski sees the early 1990s as a shift, what he calls a "synthesis" between urban city culture and rural village cultures. However, there were other musical syntheses occurring as well. The popular band Anastasia formed in the late 1980s and was known for combining Byzantine vocal music with contemporary styles. Anastasia musicians Goran Trajkoski and Zlatko Origjanski became interested in Macedonian traditional music and visited Dautovski's rehearsals to learn more about it. In 1993, Dautovski joined forces with the band (which also included Zoran Spasovski) in producing the score for Before the Rain. Complementing the film's narrative, the score contains overlapping elements of several genres of music from Macedonia, including Byzantine chant, Macedonian narodna muzika, Macedonian starogradska muzika, and the related Ottoman urban genre čalgija, a Macedonian musical genre that, when it first emerged in the nineteenth century, was a signifier of urban life and status among town-dwelling Muslims, Christians, and Jews (Seeman 2012). The score also features the vocals of Vanja Lazarova (b. 1930), who had been a singer employed by Macedonian Radio Television (MRT) during the Yugoslav period and was known for having performed with every major naroden ensemble in Macedonia both during and after that period. Drones and other textures played by synthesizers pervade the score, and other world music signifiers, such as Indian tabla, can be heard in several of the film's cues.

Because of the film's worldwide recognition, its soundtrack played a crucial role in stimulating interest in ethno music in Macedonia in the 1990s-the term etno muzika was first used in Macedonia during this period-and has provided continuing inspiration for the second wave of ethno bands that began in the early 2000s. For Dautovski, the Before the Rain soundtrack was his first experience in combining traditional music with contemporary sounds, though he had performed in rock bands since even before he became interested in traditional music. "That was my synthesis", he told me. He added that the film was "an indicator, a signal that this kind of form, combination, or synthesis could pass, that it holds water, and that a lot of groups in the world were already doing this, like Dead Can Dance, forms of New Age music." ${ }^{\prime 6}$ Indeed, the Serbian ethno music scene, also first active in the 1990s, frequently featured a similar synthesis of Byzantine Orthodox and folk traditions, gesturing towards a unity between the religious and the rural (Čolović 2004, pp. 59-62; summarized in Medić 2014, p. 113), both of which, in both countries, have come to signify and serve the national (Risteski 2009; Wilson 2019).

Subsequent to the film, Dautovski formed the group DD Synthesis (Dragan Dautovski Synthesis), and the group released an eponymous album in 1996 on SJF Records. DD Synthesis included three female vocalists, Aneta Šulankovska, Biljana Ristevska, and Mirjana Joševska, as well as Dautovski on gajda, tambura, kaval, and zurla (shawm); Marjan Jovanovski on tambura and guitar; Vančo Jovčev on piano and synthesizers; Radoslav Šutevski on drums; and Goce Usunski on tapan, tarabuka (hour glass-shaped drum) and other percussion. The aesthetics of the first album shared much in common with the score of Before the Rain (without the emphasis on Byzantine music). At the time, Dautovski described his inspiration for forming the group in a press interview:

6 Dead Can Dance is a British-Australian band known for combining traditional musics of the world, drawing from Bulgarian, North African, Arab, and Irish folk styles, among others. Their fifth album, Into the Labyrinth (1993), was popular worldwide, appearing in the Billboard 200 and likely on the radar of Dautovski and others. See (Yri 2008), which situates the fifth Dead Can Dance album, A Passage in Time, as a classic example of orientalism and exoticism. 
The rejuvenation of traditional instruments, the preservation of Macedonian folklore [...] all that just inspired me to make a group that will do just that, continue the Macedonian tradition, though in a new form that is in step with the times in which we live.

(Čanakjevikj 1998)

In the same interview, he describes the musical characteristics of the group more specifically as grounded in styles of traditional music of Macedonia and the surrounding region, including narodni instruments, a nasal timbre in the vocals, and melodies with characteristics drawn from folk music from all parts of Macedonia, "which means that through the songs of the group one can see and hear the complete folklore of our country" (ibid.). DD Synthesis seems to fit in with global trends in world music of the 1990s where stereotypes of people groups as timeless, natural, or exotic, are re-inscribed (cf. Taylor 1997, 2001; Feld 2000a), and the band did enjoy a period of international success, particularly on the European world music festival circuit. The music of DD Synthesis affirms a "timeless" or "natural" Macedonian ethnicity, which not only aligned the group with trends in world music at the time, but also, amidst contestations to Macedonian distinctiveness, excited audiences at home. Dautovski's rhetoric is quite distant from an autobalkanization of the group's music; it is not indicative of a wild, untamed incomplete self or partial Other of Europe. Instead, he seems to argue that performing Macedonian traditions reveals a complete self and that engaging with contemporary styles in hybridized forms is a significant element of the preservation of those traditions.

Dautovski recognizes the significance of narodni artists, who carried musical knowledge and expertise learned in their rural upbringings, and differentiates himself from them as a university-educated musician who began studying traditional music later in life. In my conversations with him, he suggests that anyone may drink from the "great wellspring" (izvorište) of the traditional music of Macedonia, stating that he returns to that wellspring to drink "clean water" (čista voda) time and time again. ${ }^{7}$ He suggests that all musical traditions have such great wellsprings that serve to refresh, relax, inspire, and stimulate musicians to new creativity. If a musician drinks from the great wellspring, Dautovski says, "you have quenched your thirst, you have satisfied yourself with water, with what you were thirsting for. And then, all at once, you can continue your path fresh. Actually, that is freshness, that is autochthony, that is authenticity." In this way, he suggests a shift in the discourse of "authenticity" away from an impossibly absolute purity of some unchanging, fixed, and ancient form of musical expression. He links it instead to "freshness", implying that the wellspring has an important role in inspiring new directions and new modes of expression. In a sense, he uses the metaphor of the wellspring to conflate images of the old and the ancient with ideas of the fresh and the new. He implies that "authentic" music must be connected to both the old and the new. In line with hybridity as a highly valued sign of authenticity in world music, Dautovski is clear that authentic music must be in dialogue with its source and relevant to its current world.

However, not all hybrids participate in this cosmopolitan revival of traditional music that is viewed as national. This renewed interest in traditional music demonstrated a turn away from particular hybrids that had grown out of novokomponirana narodna muzika throughout southeast Europe, known as turbofolk in former Yugoslavia and chalga in Bulgaria. Similar to ethno music, turbofolk also combines elements of traditional music with contemporary sounds, but it is known more for its reliance on electronic sounds and beats from disco, hip hop, and electronic dance music. Partially because of its overt eroticism and decadence, turbofolk tends to be positioned in academic discourse as lowbrow, vulgar music and is often associated with the violence of the Milošević regime in Serbia in the 1990s, although those discourses have been challenged (Atanasovski 2012). ${ }^{8}$ Macedonian

7 Izvorište is the augmentative and/or collective form of izvor (source or wellspring). Dautovski's use of the term connects his rhetoric to izvorna muzika (music from the source or wellspring) a type of nardona muzika that was passed down by oral tradition, romanticized and constructed as timeless and ancient under Yugoslavia.

8 Though my focus is not on comparing ethno music with turbofolk, turbofolk is also positioned towards national and regional audiences, not the world music market. Many other issues are also at play in differentiating between these musics, including 
ethnomusicologist Velika Stojkova Serafimovska similarly distinguishes this 1990s urban revival of traditional music in Macedonia, especially the use of narodni instruments, as distant from the lowbrow. She argues that it created a space for "the protection of Macedonian music and musical culture from the danger of the penetration of so-called 'turbofolk' which was being practiced on a massive scale in neighboring Serbia and Bulgaria, and in Bosnia-Herzegovina" (Stojkova Serafimovska 2014, p. 206). Situating the traditional music urban revival as a middle-class, proper, and not "dangerous" way of promoting folklore set the stage for ethno music to develop along the same class-related lines and mirrors discourses in Serbian ethno music that emphasize contrasts with turbofolk (Medić 2014, p. 111; Vesić 2009).

Interest in various forms of traditional music continued to grow among the urban middle class in Macedonia, and institutions for formal music education began to respond to and further stimulate this interest. Dautovski continued his work as a pedagogue, which he views as central to his life's work. In addition to founding narodna music programs in several elementary schools, he also founded the department of narodni instruments at the Faculty of Musical Arts at the state university in Skopje in 1993 and also founded similar departments in Macedonia's two music high schools (in Skopje and in the east Macedonian town of Štip). This has both stimulated and nurtured the urbanization of rural village music and traditional music more broadly. Musicians trained in narodni instrumental performance and singing styles began to graduate from these programs and forge careers in music. By the mid-2000s, a new generation of musicians and ensembles had emerged, and they initiated new trends that revealed the persistent salience of Macedonia's political struggles for international recognition.

\section{The Second Wave of Ethno Bands}

A new wave of ethno bands began to emerge beginning around 2005, with prominent groups including Baklava, Ljubojna, Monistra, and Chalgia Sound System. These groups share in common that they tend to draw on a wide range of musical styles and genres while grounding their music as distinctively Macedonian, an extension of the philosophy of authenticity articulated by Dautovski. For example, an online bio of Ljubojna states that the group "most authentically conveys the pulse of the Macedonian traditional sound, [and] has not only founded its work on its descending to the 'source' but deeply immerses into what we call contemporary sound, the Macedonian music of the 21st Century [sic] with all its passion and vigor" (Ljubojna Macedonian Band 2020). In the same bio they define their music in opposition to turbofolk, which they see as birthed from a suffocating "closed political direction" (ibid.). Baklava's bio from 2010 indicates that "Baklava's worldview is open to other folk traditions [...] but the key challenge is to create original music in a vivid dialogue with the aesthetic achievements of traditional Macedonian music" (Baklava 2020). While Ljubojna's reference to "passion and vigor" gestures towards stereotypes of the untamed internal Other of Europe, both bands squarely position their representation as Macedonian rather than as Balkan.

Two trends became prominent among this second wave of ethno bands. The first was the rise in the practice of performing and recording songs from the folk repertoire of ethnic Macedonians in northern Greece (referred to by Macedonians as "Aegean Macedonia"). Songs from this region were popularized during the Yugoslav period by ensembles such as the female vocal quartet "Bapčorki", which formed in 1971. Two members of Bapčorki, cousins Dosta Donevska and Leta Bardžijeva, fled their northern Greek home village of Bapčor (Gr. Pimeniko) in 1948 as refugees from the Greek Civil War. Located near Kostur (Gr. Kastoria), Bapčor, similar to many other villages in northern Greece, was destroyed in the war. The group recorded many folk songs from Aegean Macedonia for Radio Television Skopje (the state media network under Yugoslavia, which became MRT), and as a result, the

those of class, gender, sexual orientation, national identity, and variegated expressions of orientalism. The extensive academic literature on turbofolk deals with many of these issues. (e.g., Kronja 2004; Baker 2007; Rasmussen 2007; Archer 2012; Čvoro 2014). 
songs became well known. On its first album, DD Synthesis recorded an arrangement of one of these songs, "Ajde Pominuvam Zaminuvam" ("Hey, I Pass By, I Go Away”), from the Lerin (Gr. Florina) region of northern Greece.

With the second wave of ethno bands, a number of songs from Aegean Macedonia became popular throughout Macedonia. Stojkova Serafimovska attests to the fact that, in the mid-2000s, Macedonia's National Ensemble of Narodni Dances and Songs, Tanec, was turning to the archives of MRT for new material and began to draw on the recorded materials of Bapčorki, among other groups (Stojkova Serafimovska 2014, pp. 221-26). Stojkova Serafimovska suggests that renewed public discourse regarding ethnic Macedonian refugees who fled the Greek Civil War in 1948 in combination with desires to demonstrate the uniqueness of a Macedonian national identity (amid Greek and other contestations) made way at this particular time for a growing interest in the history of the Aegean Macedonian region and the cultural activities surrounding that history. Elena Hristova, the vocalist for Baklava, was a member of the Tanec vocal group at the time and was introduced to the material from Aegean Macedonia in that context. Of this material, Baklava included "Mori Čupi, Kosturčanki" ("Hey You Gals from Kostur") on their eponymous 2006 album and "Tvojte Oči, Leno Mori" (Your Eyes, Dear Lena) on their 2008 album Kalemar (meaning "grafter" or "one who grafts," as in the botanical grafting of a shoot or twig onto the trunk or stem of an existing plant, perhaps of a different variety). These two songs in particular became widely popular on YouTube, and other groups began to release their own arrangements of these songs and other music from the Aegean Macedonia region. "Tvojte Oči, Leno Mori" became the most commonly recorded and performed song by ethno bands, a part of the repertoire of Tanec, and a popular request for wedding bands and at other social occasions (ibid.). An instrumental orchestral version of "Mori Čupi, Kosturčanki" appears in the opening of the Milčo Mančevski film Mothers (2010), as various sites from Skopje are depicted, and its melody continues throughout the film as a recurring theme.

The second trend is the increasing popularity of the čalgija genre in second-wave ethno bands. Čalgija is an urban genre of starogradska muzika featuring a heterophonic texture and typically performed by an ensemble including kanun, violin, $u t$, clarinet, and either tarabuka or a frame drum (typically a dajre or a def). The Ottoman čalgija ensemble took shape in Macedonian towns in the nineteenth century and often included musicians who were members of diverse religious and/or ethnic communities. By the middle of the twentieth century, čalgija ensembles consisted primarily of Romani musicians, and they served Macedonian, Albanian, Turkish, Vlah, and Romani patrons, having developed extensive repertoires in Turkish light classical music, folk songs, and popular urban songs in the many languages of these communities (Seeman 2012; Silverman 2012, p. 31). During the subsequent Yugoslav period, especially in the context of the Čalgija Orchestra of MRT, musical signs of Ottoman cosmopolitanism in čalgija were gradually subjected to erasure as the genre was shaped into a homogenized symbol of Macedonian national identity that included both European sonic sensibilities and sonic markers of the "oriental". It has persisted as a national symbol, appearing in the Before the Rain soundtrack (namely the distinctive sound of the kanun), and has been adapted and adopted by ethno-band musicians in several ways to express and provide experiences of multifarious interpretations of Macedonia's Ottoman past.

Both of these trends in ethno music demonstrate how this scene is positioned towards local concerns, rather than towards world music markets. The songs from Aegean Macedonia serve to affirm the historical and current presence of a Slavic-speaking Macedonian minority in the northern region of Greece, amid Greek contestation of Macedonian cultural legitimacy that continued into the first two decades of the twenty-first century and hampered Macedonian aspirations for accession to the European Union. Čalgija, constructed as a Macedonian national sound, is celebrated as a distinctive marker of Macedonian musical identity. For each trend I provide here particular examples that demonstrate how ethno band musicians focus on these local concerns, articulating themselves as middle-class cosmopolitan subjects that are participating in a European milieu and as neither exotic outsiders nor Europe's internal Others. 


\subsection{Songs of Aegean Macedonia in the Music of Ljubojna}

The band Ljubojna was formed in 2002 and is a project of vocalist Vera Miloševska and her husband, bassist-composer Oliver (Oli) Josifovski. Each of Ljubojna's performances and recordings involves Vera and Oli, plus any number of other musicians that they engage for that particular occasion. Vera and Oli have long been involved in creating music for theatre, and their performances often feature great attention to theatrical lighting and costume production. A good deal of their earlier projects featured original compositions, though they have frequently centered their music on traditional styles and repertoires. Though they reject the term "ethno music", their practices of mixing styles from various Macedonian traditional musics together and with contemporary sounds situates them squarely within the boundaries of discourses about ethno music and ethno bands. Their second album Macedonia Fresh (2008) included an arrangement of "Tvojte Oči, Leno Mori", which originated in the region of Kostur (Gr. Kastoria) and whose text references various place-names in Aegean Macedonia. Subsequently, the band became one of the leading propagators of the repertoire from the Aegean Macedonia region.

One of Ljubojna's common practices is to create new arrangements of traditional songs, and since 2008, the group has recorded and performed countless different arrangements of "Tvojte Oči, Leno Mori" and other songs from the Aegean Macedonia region. They included it on an album titled Neizgasnati Ogništa (Unextinguished Hearths, 2014), a project that was completely financed by the Markovski family for small-scale release, in honor of Ilija M. Markov (1939-1993). Markov was born in the village Novoselani in the Kostur (Gr. Kastoria) region of Aegean Macedonia and was one of tens of thousands of child refugees of the Greek Civil War, separated from his family and sent first to Albania and then to Romania until he finished high school in 1956 and moved to Skopje. (See Monova 2002 for an anthropological study of "Aegeans" in the Republic of Macedonia, with a detailed analysis of the child refugees of the 1948 Greek Civil War.) The album included many of Ljubojna's regular collaborators, and as I was living in Skopje conducting dissertation research at the time, Oli invited me to record as a saxophonist and flutist on three of the album's tracks, one of which was the new arrangement of "Tvojte Oči, Leno Mori". After working through much of the track, Oli asked me to play my alto flute along with a repeating melodic line sung by Vera on vocables at the close of the track. I chose to play heterophonically, with jazz-oriented ornamentation and melodic phrasing, consistent with my own musical background. I played the ending of the melodic line beginning on the third degree of the minor scale and descending stepwise down to the tonic (b3-2-1), adding some ornamentation along the way. We recorded the passage several times before Oli said to me, "make sure you play the end of the phrase like this ...". He then sang the phrase ending as moving, by scale degree, b3-2-1-2-b7-1, with the most significant difference from my descending stepwise melody occurring as the phrase ended, ascending from the lowered seventh scale degree up to the first. He added, "That is the most Macedonian phrase ending of all. Hey, and that should help you with your dissertation! It's so Macedonian, you know, Before the Rain."

With his emphasis on seeking the "most Macedonian" way of performing a melody, and with his use of Before the Rain as an authoritative musical reference, Oli demonstrates that Ljubojna is focused on local concerns and with established transnational representations of Macedonian traditional music. At the time of the recording, I had no idea which part of Before the Rain he was talking about, but when I asked him about it later, he referenced a cue from the score titled "Death of Alexander", which includes Vanja Lazarova's performance of the narodna song "So Maki Sum Se Rodila" ("I Was Born with Great Troubles"). The melody he referenced was performed in the score by synthesized strings after the conclusion of Lazarova's vocals, and it repeats the same six-pitch melodic cadence (b3-2-1-2-b7-1) several times, accompanied by forceful percussion. The "Tvojte Oči" and Before the Rain melodic phrases share little other than their identical melodic contour, but by linking these melodic cadences, Oli reveals that he is attuned to a Macedonian musical continuum, where shared musical sensibilities can resonate as powerfully from a previously little-known song from the Kostur region as they can from the score to Macedonia's most renowned film. 
Ljubojna continued its focus on music from the Aegean Macedonia region as part of this musical continuum with its series of albums and concerts under the title "Ljubojna Brass Fantasy". The project features almost exclusively songs from Aegean Macedonia, arranged by Oli and performed by Vera as a soloist, backed up by a female choir and a brass band with Oli performing as a conductor and percussionist. For this project, Ljubojna contracted Romani brass musicians from the east Macedonia region near the town of Strumica near the Bulgarian border. Several Ljubojna Brass Fantasy concerts and recordings have also featured Romani trumpet virtuoso Džambo Agušev (b. 1987). After winning first prize at the Guča Trumpet Festival's international competition in 2011, Džambo became well known, performing extensively across the region, in Turkey, and around the world in concerts and festivals throughout Europe, the U.S., and Mexico. Ljubojna Brass Fantasy is another example of a cosmopolitan hybrid that brings together musicalities from different areas (e.g., repertoire from Aegean Macedonia, Romani brass bands and styles from east Macedonia, Oli, Vera, and other urban musicians). Vera described to me the group's stylistic flexibility and broad approach:

Macedonian music for us is so inspirational that you really can dress it up as you'd like. She [the music] is such a beautiful girl, I mean, she really is a girl, unfortunately raped a lot nowadays, I mean I'm sorry to put it that way, but what can I do, you know? You just put a little grey jacket on her that suits her well, because she doesn't need a lot of intervention. You don't have to do something to it. All you need to do is leave it alone and, you have to-you have to live it.

Vera's words position her as an authoritative tradition-bearer, using the violent rape metaphor to describe nameless other musicians' evident maltreatment of Macedonian traditional music and situating Ljubojna, in contrast, as an exemplary living embodiment of how to represent this music in the contemporary world. In their representation of the Ljubojna Brass Fantasy project, Vera and Oli avoid explicitly exoticist or Balkanist tropes, even as they build on the popularity of brass band music among middle-class audiences and typical patron-client relationships of ethnic Macedonians and Romani musicians for weddings and other celebrations. In staged performances of the project, Vera and the women vocalists wore traditional Macedonian village attire, while the instrumentalists (all male) wore all black concert attire, with the exception of Džambo, who wore a blue suit and white sneakers. This, and the relatively static staging of the performance, is a far cry from the raucous, wild representation typical of Goran Bregović's projects and of the Balkan brass bands that frequent the world music circuit. Ljubojna consciously distances themselves from these projects and their associations with notions of "the Balkans", aligning themselves more closely with their perceptions of European cosmopolitanism in their visual and musical aesthetics.

Since their turn towards the music of Aegean Macedonia, Ljubojna made a marked change in its representation by changing the spelling of its name to "Luboyna", beginning with its album Radio Luboyna (2017). This change arguably makes the pronunciation of the band's name easier for international audiences, creating a new brand that ostensibly removes barriers for those in the world music market without familiarity with Slavic languages. This seemed to be a strategic decision made with Geenger Records, the Croatia-based label that released the album, and rumors circulated that Ljubojna/Luboyna was working with a new manager in Serbia that had also inspired the change. ${ }^{9}$ Radio Luboyna included several tracks with their frequent collaborator Ismail Lumanovski, a Macedonia-born New York-based Romani clarinetist renowned for his virtuosity in numerous classical and traditional music styles. It also continued their work with brass band musicians (including Džambo Agušev) in arrangements that featured jazz-inflected bass lines and Rhodes electronic piano chords, hip-hop turntable scratching, the distinctive kanun timbre of čalgija, and one track dominated by sustained piano with significant reverb and reverse effects added in the recording studio ("Mnogu Mi Go Falat

9 I was not able to verify this rumor either way, but it was typically discussed in a suspicious rather than in a celebratory fashion. 
Vasheto Devojche" [I Greatly Miss Your Girl]). Some middle-class Macedonians I spoke with who would otherwise be amenable to Ljubojna's music assessed this album negatively, telling me that they perceived the group as turning towards turbofolk. According to these listeners, this was because of the turntable scratching and other electronic sounds, even though those sounds only occur occasionally on the album. Perhaps related in part to the rumors of Ljubojna's new Serbian management and the release of the album on a Croatian label, these assessments of the music associated it negatively with musical styles that might be more closely associated with the backwardness of the Balkans, even though the word "Balkan" is not deployed. Ljubojna and other bands thus walk a fine line between connecting with (and not alienating) their faithful and growing "home" audience and experimenting with changes to their style and representation alongside music industry partners outside Macedonia. While Ljubojna (or Luboyna) has enjoyed increasing success within North Macedonia and its diaspora (they completed an Australia tour in 2018), this branding change and these new combinations of styles did not result in significant growth in the band's popularity outside Macedonian circles.

\subsection{Two Approaches to Čalgija}

As the Ottoman urban genre čalgija became a trend in second-wave ethno music, musicians tended to take one of two approaches to engaging with the genre. One approach involved engaging with active lifelong practitioners of the genre such as former members of the Čalgija Orchestra of MRT, which continued to operate after Macedonia's independence in 1991. Ut player and former director of the orchestra Raim Baki and kanun player Husref (Ustrev) Said from the orchestra are both in their advanced years today but still often perform in Skopje's čaršija (old bazaar), by contract with Tanec, and in occasional hybrid projects. Bajsa Arifovska (b. 1979), a student of and later collaborator with Dragan Dautovski, is one example of a musician who became interested in čalgija in the years since the second wave of ethno bands emerged and who has engaged with living masters to learn the style. Arifovska is a middle-class Romani musician who learned traditional music in the formal education system. She also taught narodni instruments for many years in the department Dautovski founded at Skopje's music high school until she resigned in 2013 to begin working for Tanec as a full-time performer. As a multi-instrumentalist, she has diverse interests and skills, and I have known her to be contracted by the Macedonian Opera and Ballet and for countless other projects where she plays clarinet, violin, tambura, kaval, and/or percussion in traditional styles. Around 2010, Arifovska began spending time with Said and Baki, learning čalgija styles and systems of improvisation from them through playing together in a master-apprentice setting. In 2013, Arifovska released an album titled Macedonian Čalgija featuring Baki, Said, Naser Mustafa on tarabuka, and Arifovska on clarinet and violin. Though Arifovska is part of ensembles that could be considered ethno bands, this project would not be considered "ethno music", because it features čalgija music performed by čalgija musicians with no purposeful creative adaptations. Husref Said has reminded me numerous times that to learn čalgija, one needs at least twenty years of experience, learning from a master as an apprentice. Arifovska seems to have also aligned herself with this philosophy. She is aware that she is not a čalgija master, but does not hesitate to promote the music through organizing an album with the living masters of the genre as she negotiates her position as a Romani musician whose musical skill and knowledge has been, in large part, cultivated in the Macedonian system of higher education.

Other musicians and groups that are part of the ethno scene also engage with experienced čalgija practitioners but by including them in their cosmopolitan hybrid projects. I have seen Oliver Josifovski and Vera Miloševska of Ljubojna perform in a čalgija style numerous times, and in their discourse, they emphasize their consistent employment of Romani and Turkish musicians in such settings, especially those from the southern Macedonian town of Bitola, which is also Josifovski's hometown. They cite a desire to honor musical traditions and to value "authenticity" in representing musical traditions of Macedonia, which include a rich diversity of musicians. For them, performing with master musicians of čalgija not only makes their music exemplary of the riches of Macedonian traditional music, but also represents a type of Macedonian cosmopolitanism that is inclusive and celebratory of 
contributions of marginalized populations, even though ethnic Macedonians remain at the center of that representation. ${ }^{10}$

The other principal approach to čalgija among ethno bands is exemplified by the group Chalgia Sound System. This group performs songs of the čalgija repertoire, as well as other songs arranged in čalgija style, and consists of exclusively ethnic Macedonians. Having released one self-titled album in 2011, the band performs sporadically in various capacities, from gigs at local clubs to other organized sit-down concerts as part of festivals and special events. Chalgia Sound System represents itself as contemporary and cosmopolitan in their performance, distancing themselves from Balkanist tropes by, for example, avoiding traditional attire for performances and opting instead for contemporary fashions. They also show some degree of shaping their representation for audiences outside Macedonia, by using the spelling "Chalgia" in representations of their name rather than "Čalgija", in a move similar to Ljubojna's shift to Luboyna. The group formed as a result of a school for folk music organized in 2005 by Orchestra "Pece Atanasovski", an ensemble founded in 1997 in honor of renowned naroden artist Atanasovski, who had passed away in 1996. The classes met regularly, and in 2006, the school held a special seminar, where Palestinian oud and violin virtuoso Simon Shaheen was a guest artist, along with Turkish kanun player Günay Çelik. The members of Chalgia Sound System cite Shaheen and Çelik as an inspiration for the formation of their group, which consists of violin (Aleksandra Kuzman), ut (Dorian Jovanovikj), kanun (Boško Mangarovski), percussion (dajre/tarabuka, Filip Krstevski), and female vocal (Dobrila Grašeska). They do not cite contact with Said, Baki, or any of the other musicians of the MRT Čalgija Orchestra (nor other contemporary čalgija masters) in their discussions of the inspiration for their group, though they certainly grew up hearing the orchestra-Baki is especially known throughout Macedonia as the long-time director of the ensemble. Instead, in line with the way čalgija was re-fashioned and "cleaned up" by state policies under Yugoslavia, they represent čalgija as a rich treasure of Macedonian music, as an expression of various aspects of the character of ethnic Macedonians. Similar to other ethno bands, they began to capitalize on the popularity of songs from Aegean Macedonia, and they included "Mori Čupi, Kosturčanki" and "Tvojte Oči, Leno Mori" on their 2011 album.

The group's pathway to čalgija via Simon Shaheen and Günay Çelik seems to embody, at least in part, the consequences of increased ethnic separation in North Macedonia-somehow Shaheen and Çelik as outsiders were more accessible than the čalgija master musicians in Macedonia, even though those masters were well-known and not hard to find. Bajsa Arifovska, in contrast, went to Said and Baki (was she drinking from the izvorište, as her mentor Dautovski would advise?), seeking to align herself with the čalgija tradition despite the fact that she was not born into a family of čalgija musicians, that she was educated in a formal educational system, and that she was a woman playing instruments that were traditionally the domain of men. For the musicians of Chalgia Sound System, the ethnic barriers to seeking out the masters of čalgija were perhaps more insurmountable than the ones facing Arifovska, who is Romani like Said and Baki. As a result, they perhaps have unwittingly participated in the propagation of the further erasure and marginalization of minorities, inspired by Shaheen as an exotic outsider to explore the exoticness of čalgija, whose roots are in Macedonians' history with their own "Other within". ${ }^{11}$ In an ironic move of sorts, Chalgia Sound System represents itself as

10 This is a classic example of the "celebratory" narrative of world music (Feld 2000b; see also Born and Hesmondhalgh 2000). Carol Silverman, drawing on the work of Feld, interrogates this narrative, finding it overconfident about the ability of hybrid musics to induce change, especially with regard to marginalization and exploitation of Romani musicians (Silverman 2012, pp. 279-80). In the case of Ljubojna's work with Romani musicians, questions of agency and profits eluded my inquiry. Although the asymmetry of the power dynamics clearly favors Josifovski and Miloševska as ethnic Macedonians, the ongoing work of the group with the same Romani musicians in recordings, in performances, and on tours suggests that there is at least some degree of mutual benefit from the collaboration.

11 Seeman (2012, p. 322) describes this type of process as the "repressing [of] memories and experiences of shared cultural participation", which, for čalgija under Yugoslavia, took the form of sinister techniques by which musical practices were manipulated in order to dehumanize particular communities, through the narrowing of symbolic vocabulary. Such reduction enabled dominant political regimes to present different communities as de-humanized "Others", and in this case, 
a cosmopolitan group celebrating the relevance of Macedonian traditional music for contemporary audiences, avoiding self-representation as Europe's internal Other. In the process, however, they rely on the marginalization and erasure of their own internal Other, Roma, as they appeal mostly to ethnic Macedonian audiences. For the world music market outside Macedonia, Chalgia Sound System is not quite different enough to resonate with audiences looking for "authentic" hybrids of the traditional and the contemporary, and once again, the group's appeal is for the most part constrained to audiences within Macedonia.

Chalgia Sound System (2015), Ljubojna (2009 and 2017), and Baklava (2010 and 2011) have all performed as headlining artists at OFFest, an annual world music festival in Skopje featuring the biggest names on the world music festival circuit. When I first observed this trend among ethno bands, I thought that it would lead to further opportunities on the world music festival circuit, at least in Europe, because the festival is part of a collective of world music-oriented festivals called the "Forum of Worldwide Music Festivals" (FWMF). ${ }^{12}$ This network of festivals is known to gather at WOMEX and other world music industry events where artists are showcased and decisions to coordinate and "share" artists among festivals are made. In this way, festivals seek to minimize operational costs for artists' travel, tending to all feature more or less the same artists in a given year and playing a significant role in facilitating international renown and, ostensibly, economic gain for particular artists and groups. However, Macedonian ethno bands who had performed at OFFest have not gained many performance opportunities on the world music festival circuit through FWMF. Their performances at OFFest seemed to be simply one-off opportunities to be a featured group at one of Macedonia's most prestigious music events (at a low cost to the festival, compared to the costs involved in bringing in groups from abroad). The director of OFFest, Oliver Belopeta, is famously tightlipped about festival organization, budgets and funding, and how FWMF works. In North Macedonia, he is perceived as a powerful gatekeeper to the world music festival circuit, but regardless of whether or not he pitches Macedonian ethno bands to other festivals, these other member festivals of FWMF have not engaged ethno bands, even though the organizers of these festivals would likely be aware of these bands from OFFest annual programs and other materials. Perhaps they perceive the bands as not appealing to the exoticizing gaze of audiences, but perhaps they also have not had these bands directly pitched to them as potential performers. Ethno bands are typically self-managed, and while Ljubojna seems to have attempted to connect with music industry networks outside Macedonia, most of these groups would not have opportunities to directly pitch themselves to festival organizers without a manager or other intermediary. These dynamics and processes, intertwined as they are with changing world music industry trends and access to industry advocates, also play a role in constraining the appeal of ethno bands.

\section{Karolina Gočeva and Pop Music in the Wake of Ethno Trends}

For my final case, I turn to the latest project of pop singer Karolina Gočeva (b. 1980, Bitola), known simply as Karolina, one of the most well-known individuals in Macedonia. Karolina's career began when she was a teenager, and she has released many hit songs and albums, maintaining a high level of popularity and public visibility since the late 1990s. In the course of her career, Karolina has become to some extent a national symbol for Macedonia. In addition to two appearances as Macedonia's representative at the Eurovision Song Contest in 2002 and 2007, she was featured in one of the central performances at Macedonia's celebration of twenty years of independence in 2011. Her music has covered broad stylistic ground within commercial pop categories (e.g., R\&B, hip-hop, rock), but never approached anything considered "ethno" or traditional until her 2008 release of the

excludes them from participation in a new cosmopolitan manifestation of a musical genre that they have sustained for several generations.

12 See http://www.fwmf.world/about/ (accessed on 3 March 2020). 
album Makedonsko Devojče (Macedonian Girl). The songs on the album drew on traditional styles and were all original compositions with music and lyrics by Zlatko Origjanski of Anastasia. The album enjoyed wide popularity in Macedonia, was also released in the Serbian market, and was followed several years later with the album Makedonsko Devojče 2 (2014). ${ }^{13}$ For this project, Karolina and her management team at Avalon Production engaged pianist/keyboardist Nikolče Micevski as the primary composer/arranger and music director and Valentin Sokolevski as the primary lyricist. The album and its associated concerts included many musicians active in the ethno music scene, such as Oliver Josifovski of Ljubojna (bass), clarinetist Blagojče Trajkovski (a frequent performer with Ljubojna), kanun player Boško Mangarovski of Chalgia Sound System, and Romani trumpet player Džambo Agušev. The project not only demonstrates how ethno music has influenced popular music in Macedonia more broadly, but also shows, through its collection of musicians, how the cosmopolitan musical practices of the ethno music scene are interconnected in a network of musicians who contribute the hybridizing musical skills and the styles for which they are known to multiple projects.

Makedonsko Devojče 2 was released with a slick marketing campaign to great fanfare in February 2014, when Karolina also performed six sold-out concerts on consecutive nights at the Macedonian Opera and Ballet. Though she is not part of the ethno band scene, the original songs on this album were arranged in a style that could be considered "ethno music", drawing on urban styles of Macedonian traditional music in combination with elements labeled by composer/arranger Micevski as "jazz" and "pop". The first single from the album, "Čalgiska", as evident in its title (the feminine adjective form of čalgija that would modify the word "song" or pesna), follows the trend of incorporating čalgija elements into ethno music. It features Mangarovski on kanun and, similar to many of the songs, a text full of Turkisms in the Macedonian language both common and poetic. "Čalgiska" is not in a čalgija style per se but includes the timbre of the kanun as a strong signifier of čalgija. In an interview with me, arranger Micevski situated the timbre of the kanun thus: "The interesting thing about the kanun is that for $90 \%$ of the songs, if they would be played by the kanun and played well, the sound of the kanun itself would give them a čalgija sound, a čalgija style." The strong association of the timbre of the kanun with čalgija indexes the genre for the audience along with all of its self-orientalizing meanings that have attached the genre to Macedonian national identity.

When I spoke with Micevski about the project after its release, he said that the goal was "to make something folk, but not folk ... somehow for it to still belong in ethno or world music." He spoke in great detail about how it was important to add the correct "spices" to the music-harmonic elements from European classical music, dominant and extended dominant chords that he characterizes as "jazz", some traditional elements but not others (there is no kaval, gajda, tapan, or zurla; i.e., no indexing of rural village music), and some pop sensibilities in Karolina's vocal performance. The hope was to go even deeper into traditional music styles than the first Makedonsko Devojče album and to create new music along the lines of the starogradska muzika genre, without venturing too far into rural village (narodna or izvorna) music sensibilities or turbofolk aesthetics (and its influences from disco, hip-hop, and electronic music).

Micevski told me about the success of one of the songs, "Dve Liri" (Two Turkish Liras), suggesting that its music and its lyrics touched people's souls:

So it's not typical folk music, but I'll say it again, it has a soul. We touched the soul. "Dve Liri" became a hit in three days, you understand? It's typically Macedonian [in its musical aspects]. On the other hand, the lyrics tell a story that is also typical for these parts, about how a grandmother left two gold liras so that her grandchild could use them to request a song in her honor at his wedding, after the grandmother had passed. Everyone, or every other person has had that kind of experience. Those days might be over now, we live in

13 These albums were both named after the song "Makedonsko Devojče", a newly-composed narodna song written in 1964 by Jonče Hristovski (1931-2000) that is often performed in starogradski style. The song does not appear on either album. 
a different time, but in the eighties, we still had our grandmothers and grandfathers, you understand? So that's the combination that reached everyone. "Wow, the story! It reminded me," they say, "of my own grandmother." No way it won't remind you, right?

The concerts at the opera house were all filled to that hall's 700-seat capacity with Macedonians of all ages. Karolina and the band dressed in attire referencing early twentieth-century urban styles: Karolina in modest, vaguely retro dresses and vintage hats; the men in vests, ties, suspenders, and flat, newsboy-style caps. After each concert, Karolina and several of the band members hurried out to the lobby of the opera house, where a small stage was set up. They reprised several of the songs in this more intimate setting, where audience members were in close proximity to Karolina and the other musicians, just as they would be if a čalgija or other starogradski band was playing at a restaurant. People crowded onto the stairs and the balcony of the lobby, and many had their smartphones out and were recording videos as she performed "Čalgiska" and "Dve Liri", the most well-known songs from the album. Audience members were continuing their experience of the music from the concert, singing along, clapping, and raising their hands in the air with smiling faces as they enjoyed being part of a moment that perhaps gave them nostalgia for lost relatives or provided an experience of being part of something distinctly Macedonian.

Makedonsko Devojče 2 and its release follow the tendencies in ethno music to embody a middle-class cosmopolitan manifestation of hybridized traditional music in terms of instrumentation, musical style, and visual representation. The project draws particularly on ethno-music trends in relying on čalgija styles, affirming the genre as a Macedonian national one that has incorporated, and to some extent erased, the Ottoman legacy of Macedonia's "Others within", in this case, Roma and Turks. These strategies of Karolina and her management team at Avalon Production had great appeal in Macedonia, as evidenced by the six sold-out concerts at the opera house, appealing to an ethnic Macedonian audience by following the common trope of a female vocalist backed up by a band constituted by all ethnic Macedonian males and Romani trumpet player Džambo Agušev. Similar to ethno bands, the project is clearly focused on an ethnic Macedonian public, as it evokes nostalgia, memory, and lived experience through references and associations meaningful primarily to ethnic Macedonians. In a conversation I had with a member of Karolina's management team soon after the album came out, it seemed that there was at least some effort to pitch the project to world music festivals in a bid to break her into that network. However, like the second-wave ethno bands, Karolina did not become a fixture in the world music network, and her appeal has been constrained primarily to ethnic Macedonian audiences.

\section{Conclusions}

Macedonian ethno bands today, along with artists such as Karolina who have built on their trends, avoid the use of the word Balkan in their self-representation and, for the most part, avoid stereotypical Balkanist tropes of wild abandon common in the world music circuit. They focus on musical elements that resonate with Macedonian audiences, such as the songs of Aegean Macedonia and čalgija, elements that serve to reaffirm identity questions for ethnic Macedonians and provide experiential cosmopolitan signifiers of belonging in contemporary European society. As they experience success among Macedonian audiences, these musicians express desires to expand their audiences beyond Macedonian ones, and the world music market seems to be among the most sensible venues for them to pursue. However, as Aleysia Whitmore contends, music industry personnel "discipline and manage musics by reproducing stereotypes and placing limits on how audiences perceive musicians [...] They create a straw man against which Westerners define themselves and that justifies treating the 'Other' differently" (Whitmore 2016, p. 333). Musicians in the Macedonian ethno music scene resist becoming this kind of "straw man", asserting instead that they belong among "Westerners" and refusing to be defined by stereotypes and limits that might be placed on them. They demonstrate sophistication in combining any number of musical styles as they appeal to their cosmopolitan audience of middle-class Macedonians. As they do so, they become less appealing to those with 
power in the world music market, because they are perceived as not quite different enough to appeal to the exoticizing gaze of world music audiences. In their widely successful efforts to resonate with Macedonian audiences, ethno bands situate Macedonians not as Europe's Balkan "partial Other" or "incomplete self", but as full participants in cosmopolitan Europe. As a result, they cannot be a Balkan object of a European gaze, and their appeal for world music markets in Europe and in related networks is limited.

Funding: This research was funded by the American Council of Learned Societies, the American Councils of International Education, the Herb Alpert Foundation, and the UCLA Graduate Division.

Acknowledgments: I thank all of the musicians who generously gave their time and energy for interviews and other conversations that constituted this research, including Bajsa Arifovska, Raim Baki, Dragan Dautovski, Ratko Dautovski, Karolina Gočeva, Dobrila Grašeska, Oliver Josifovski, Nikolče Micevski, Vera Miloševska, and Husref Said. I also am ever grateful to Ana Grujoska, Ilija Grujoski, and Simon Stojanovski, whose perspectives have shaped this article and so much of my work. Victor Friedman, Jane Sugarman, and Carol Silverman provided comments on earlier versions of this article, for which I thank them. All errors in this article are mine alone.

Conflicts of Interest: The author declares no conflict of interest.

\section{References}

Archer, Rory. 2012. Assessing Turbofolk Controversies: Popular Music between the Nation and the Balkans. Southeastern Europe 36: 178-207. [CrossRef]

Atanasovski, Srđan. 2012. Turbo-folk as “Bad Music”: Politics of Musical Valuing. In Böse Macht Musik Zur Ästhetik des Bösen in der Musik. Edited by Katharina Wisotzki and Sarah R. Falke. Bielefeld: Transcript, pp. 157-72.

Baker, Catherine. 2007. The Concept of Turbofolk in Croatia: Inclusion/Exclusion of National Musical Identity. In Nation in Formation: Inclusion and Exclusion in Central and Eastern Europe. Edited by Catherine Baker, Christopher J. Gerry, Barbara Madaj, Liz Mellish and Jana Nahodil. London: SSEES Occasional Papers, pp. 139-58.

Bakić-Hayden, Milica. 1995. Nesting Orientalisms: The Case of Former Yugoslavia. Slavic Review 54: 917-31. [CrossRef]

Baklava. 2020. Culture Map. Available online: http://culturemap.mk/artisti/muzika/etno-muzika/baklava (accessed on 13 January 2020).

Born, Georgia, and David Hesmondhalgh. 2000. Introduction: On Difference, Representation, and Appropriation in Music. In Western Music and Its Others: Difference, Representation, and Appropriation in Music. Edited by Georgina Born and David Hesmondhalgh. Berkeley: University of California Press, pp. 1-58.

Buchanan, Donna A. 2006. Performing Democracy: Bulgarian Music and Musicians in Transition. Chicago: University of Chicago Press.

Čanakjevikj, Maja. 1998. Intervju so Dragan Dautovski. Blesok. Available online: http://blesok.mk/en/sound/ reviews-sound/interview-with-dragan-dautovski-02/ (accessed on 9 January 2020).

Čolović, Ivan. 2004. Balkan u naraciji o world muzici u Srbiji. New Sound 24: 59-62.

Čvoro, Uros. 2014. Turbo-Folk Music and Cultural Representations of National Identity in Former Yugoslavia. Burlington: Ashgate.

Dimova, Rozita. 2003. Lost Objects: Ethnicity, Consumption, and Gendered Spaces in Contemporary Macedonia. Ph.D. dissertation, Stanford University, Stanford, CA, USA.

Dumnić, Marija. 2012. This Is the Balkans: Constructing Positive Stereotypes about the Balkans and Autobalkanism. In Musical Practices in the Balkans: Ethnomusicological Perspectives-Proceedings of the International Conference Held from November 23 to 25, 2011. Edited by Dejan Despić, Jelena Jovanović and Danka Lajić-Mihajlović. Belgrade: Serbian Academy of Sciences and Arts, pp. 345-56.

Feld, Steven. 1996. pygmy POP. A Genealogy of Schizophonic Mimesis. Yearbook for Traditional Music 28: 1-35. [CrossRef]

Feld, Steven. 2000a. The Poetics and Politics of Pygmy Pop. In Western Music and Its Others: Difference, Representation, and Appropriation in Music. Edited by Georgina Born and David Hesmondhalgh. Berkeley: University of California Press, pp. 254-79.

Feld, Steven. 2000b. A Sweet Lullaby for World Music. Public Culture 12: 145-71. [CrossRef]

Feld, Steven. 2012. Jazz Cosmopolitanism in Accra: Five Musical Years in Ghana. Durham: Duke University Press. 
Guy, Nancy. 2002. Trafficking in Taiwan Aboriginal Voices. In Handle with Care: Ownership and Control of Ethnographic Materials. Edited by Sjoerd R. Jaarsma. Pittsburgh: University of Pittsburgh Press, pp. 195-209.

Hofman, Ana. 2014. Balkan Music Awards: Popular Music Industries in the Balkans between Already-Europe and Europe-To-Be. In Mirroring Europe: Ideas of Europe and Europeanization in Balkan Societies. Edited by Tanja Petrović. Leiden: Brill, pp. 41-63.

Kronja, Ivana. 2004. Turbo Folk and Dance Music in 1990s Serbia: Media, Ideology and the Production of Spectacle. Anthropology of East Europe Review 22: 103-14.

Laušević, Mirjana. 2007. Balkan Fascination: Creating an Alternative Music Culture in America. New York: Oxford University Press.

Ljubojna Macedonian Band. 2020. Virtual Macedonia. Available online: https://vmacedonia.com/culture/music/ ljubojna.html (accessed on 13 January 2020).

Marković, Aleksandra. 2008. Goran Bregović, the Balkan Music Composer. Etnologia Balkanica 12: 9-23.

Marković, Aleksandra. 2009. Sampling Artists: Gypsy Images in Goran Bregovic's Music. In Voices of the Weak: Music and Minorities. Edited by Zuzana Jurkova and Lee Bidgood. Prague: NGO Slovo21, pp. 108-21.

Marković, Aleksandra. 2013. Sounding Stereotypes: Construction of Place and Reproduction of Metaphors in the Music of Goran Bregović. Ph.D. dissertation, University of Amsterdam, Amsterdam, The Netherlands.

Marković, Alexander. 2015. "So That We Look More Gypsy": Strategic Performances and Ambivalent Discourses of Romani Brass for the World Music Scene. Ethnomusicology Forum 24: 60-85. [CrossRef]

Medić, Ivana. 2014. Arhai's Balkan Folktronica: Serbian Ethno Music Reimagined for British Market. Muzikologija 16: 105-27. [CrossRef]

Meintjes, Louise. 1990. Paul Simon's Graceland, South Africa, and the Mediation of Musical Meaning. Ethnomusicology 34: 37-73. [CrossRef]

Monova, Miladina. 2002. Parcours d'exil, récits de non-retour: Les Égéens en République de Macédoine. Ph.D. dissertation, École des Hautes Études en Sciences Sociales, Paris, France.

Neofotistos, Vasiliki P. 2008. “The Balkans' Other within": Imaginings of the West in the Republic of Macedonia. History and Anthropology 19: 17-36. [CrossRef]

Neofotistos, Vasiliki P. 2011. Going Home to Pakistan: Identity and Its Discontents in Southeastern Europe. Identities 18: 291-316. [CrossRef]

Rasmussen, Ljerka V. 2002. Newly Composed Folk Music of Yugoslavia. New York: Routledge.

Rasmussen, Ljerka V. 2007. Bosnian and Serbian Popular Music in the 1990s: Divergent Paths, Conflicting Meanings, and Shared Sentiments. In Balkan Popular Culture and the Ottoman Ecumene: Music, Image, and Regional Political Discourse. Edited by Donna A. Buchanan. Landham: Scarecrow Press, pp. 77-114.

Risteski, Ljupčo S. 2009. Priznavanjeto na avtokefalnosta na Makedonskata pravoslavna crkva (MPC) kako prashanje na makedonskiot nacionalen identitet. (Recognition of the independence of the Macedonian orthodox church (MOC) as an issue concerning Macedonian national identity.). EthnoAnthroZoom 6: 144-88.

Seeman, Sonia Tamar. 2012. Macedonian Čalgija: A Musical Refashioning of National Identity. Ethnomusicology Forum 21: 295-326. [CrossRef]

Silverman, Carol. 2012. Romani Routes: Cultural Politics and Balkan Music in Diaspora. Oxford: Oxford University Press.

Silverman, Carol. 2013. Global Balkan Gypsy Music: Issues of Migration, Appropriation, and Representation. In The Globalization of Musics in Transit: Musical Migration and Tourism. Edited by Simone Krüger and Ruxandra Trandafoiu. London: Routledge, pp. 185-208.

Spivak, Gayatri C. 1987. In Other Worlds: Essays in Cultural Politics. New York: Methuen.

Stojkova Serafimovska, Velika. 2014. Makedonskata Vokalna Muzička Tradicija vo Procesot na Opštestvenata Tranzicija. Ph.D. dissertation, Sts. Cyril and Methodius University, Skopje, Macedonia.

Stokes, Martin. 2007. Shedding Light on the Balkans: Sezen Aksu's Anatolian Pop. In Balkan Popular Culture and the Ottoman Ecumene: Music, Image, and Regional Political Discourse. Edited by Donna Buchanan. Lanham: Scarecrow Press, pp. 309-34.

Taylor, Timothy D. 1997. Global Pop: World Music, World Markets. New York: Routledge.

Taylor, Timothy D. 2001. Strange Sounds: Music, Technology, and Culture. New York: Routledge.

Taylor, Timothy D. 2003. A Riddle Wrapped in a Mystery: Transnational Music Sampling and Enigma's "Return to Innocence.". In Music and Technoculture. Edited by René T. A. Lysloff and Leslie C. Gay Jr. Middletown: Wesleyan University Press, pp. 64-92. 
Thiessen, Ilká. 2006. Waiting for Macedonia: Identity in a Changing World. Orchard Park: Broadview Press.

Tochka, Nicholas. 2017. Cosmopolitan Inscriptions? Mimicry, Rap, and Rurbanity in Post-1997 Albania. In Hip Hop at Europe's Edge: Music, Agency, and Social Change. Edited by Milosz Miszczynski and Adriana Helbig. Bloomington: Indiana University Press, pp. 165-81.

Todorova, Maria. 2009. Imagining the Balkans, Updated ed. New York: Oxford University Press.

Turino, Thomas. 2000. Nationalists, Cosmopolitans, and Popular Music in Zimbabwe. Chicago: University of Chicago Press.

van Klyton, Aaron. 2014. All the Way from..., Authenticity and Distance in World Music Production. Cultural Studies 30: 106-28. [CrossRef]

Vesić, Ivana. 2009. Produkcija i promocija etno-muzike u Srbiji nakon 5 oktobra 2000 godine: Društvena i kulturna transformacija sagledana na primeru delovanja medijskih kuća RTS i B-92. Master's thesis, University of Belgrade, Belgrade, Serbia.

Weiss, Sarah. 2014. Listening to the World but Hearing Ourselves: Hybridity and Perceptions of Authenticity in World Music. Ethnomusicology 58: 506-25. [CrossRef]

Whitmore, Aleysia K. 2016. The Art of Representing the Other: Industry Personnel in the World Music Industry. Ethnomusicology 60: 329-55. [CrossRef]

Wilson, Dave. 2019. Shaping the Past and Creating the Future: Music, Nationalism, and the Negotiation of Cultural Memory at Macedonia's Celebration of Twenty Years of Independence. Music E Politics 13. [CrossRef]

Yri, Kirsten. 2008. Medievalism and Exoticism in the Music of Dead Can Dance. Current Musicology 85: 53-72.

(C) 2020 by the author. Licensee MDPI, Basel, Switzerland. This article is an open access article distributed under the terms and conditions of the Creative Commons Attribution (CC BY) license (http://creativecommons.org/licenses/by/4.0/). 